\title{
The Effectiveness of Social Media Marketing to Introduce Tenun Products
}

\author{
I Gusti Ayu Melistyari Dewi \\ DIII Hospitality \\ Sekolah Tinggi Pariwisata Bali Internasional \\ Denpasar, Indonesia \\ melistyari.dewi@gmail.com
}

\begin{abstract}
Products are part of tourism attraction that has most important role in attracting tourists to visit particular tourism spot. In the progress, some tourism products will be competing at each other to get the interest of the tourists. Many have done many things to introduce their tourism products that represent their area, which one of them through the latest marketing strategy, by utilizing social media. The presence of social media these days has become a basic need of mankind, especially the younger generation. It is the basis for the emergence of social media marketing that has also been done by the tourism actors, including by Ananda Tenun Bali Denpasar. In introducing its products, Ananda Tenun Bali always post their latest products in their facebook page, instagram, and twitter, one of which is a woven fabric that is consider as the special characteristic of Denpasar. Based on this insight, this study aims to look at the effectiveness of social media marketing that is done by Ananda Tenun Bali Denpasar in introducing their products. This study is using descriptive method of data collection, either through interviews, questionnaires and data that have been owned privately by Ananda Tenun Bali such as sales data. The results of these studies find that it turns out social media marketing methods that have been done by Ananda Tenun Bali is quite effective. The finding is supported by Ananda's rapid online sales. In addition, many visitors who visit Anada textile know the products through social media. Indeed, trends of Ananda visitors who know their products through social media are dominated by young people, but not least there are also old people who are usually introduced of these products by their children who know the products from social media. So it can be concluded that the role of social media marketing is quite effective in introducing Ananda Tenun Bali products. They idea could also be conducted by other product manufacturers who wish to introduce their products.
\end{abstract}

Keywords-Woven Fabrics, Social media marketing, Tourism Attraction

\section{INTRODUCTION}

World tourism is becoming one of country's main supports of an income. In Indonesia, tourism sector has brought employment to many industries that handle 9.5 million visits on the last 2014 (Data from Board of Statistic per 2015). There are varied reasons why tourists in determining whether an area is worth visiting or not, so it becomes a tourist destination in itself. Among those vary reasons are because of the nature, culture, customs, to the variety of craft products of it societies. From this reason, products become one of main tourist attractions because the without attraction, there won't be some to see or do or buy in the particular place (Yoeti. 1997). There are many tourism products that have been attracting by the tourists, including cultural products. The cultural product became well known for successfully representing the power of creativity and culture of the local people who generally as a tradition inherited from their ancestors.

In Bali, it has been known for its numerous cultural products which hold prominent attraction along with one of the best world cultural tourism destination. Almost all crafts that are created by Balinese became world famous, including painting, carving, weaving, and also works of movement (dancing). Those local products are a work that is much related to one another under the influence of Balinese culture, with the understanding and religion of Hindu, so intertwined between one and the other. One particular cultural product which is also as the subject of the present study is Balinese woven fabric products or Tenun, which are well known and has decorated famous galleries across the country.

Weaving activities have been handed down on the island for hundreds of years (Wirawan et.al. 2011. Adnyani. 2013. Kustiasih.2014). Not only one, there are some varieties of the weaving art which produce many products that are created on the island. In the east part of Bali, Karangasem, they have Tenun

Pegringsingan which is already well known by the world. In Klungkung regency, Nusa Penida, they have Rangrang and Cepuk woven. Then there is also Songket from various districts in Bali, as well as woven fabrics called Endek which is also owned by various districts, including the city of Denpasar.

Kain Ikat Bali or Endek is a form of cultural product that was initially used only by parents and nobility, but now most of the Balinese people can use them, whether for big ceremony or prayer to the Temple. Endek resulting from weaving industry in Bali has averagely still using traditional motifs and designs, some of which are only used during the village ceremony. Those fabrics called Wastra in Balinese, has very important role during ceremonies. Even Endek has some of certain decoration that is sacredly connected during ceremonies or can only be 
used by certain people (Utami, 2015). By that cause, Endek as a culture product must be preserved but should, so it can undermine the value of maintained culture.

As the tourism sector develops rapidly, Endek is not only produced in the form of cloth or Wastra, Endek is already applied in the form of clothing design like handbags, wallets, or gifts to attract consumers (Putri, et.al. 2015). Endek motives are more diverse but still do not leave the typical pattern of Endek weaving itself. This is issue is what being developed in Denpasar. In addition to help the economy of the craftsmen, it is also expected to increase the interest of tourists to the Endek of Denpasar. Based on the results of preliminary observations, tourists that are interested in Endek Denpasar are mostly dominated by domestic tourists as well as the Japanese. Domestic travelers generally like Endek in the form of clothing, handbags, or wallets, while the foreign tourists are likely to enjoy Endek cloth in the form sheet. To introduce the existence of this woven fabric, it requires different ways of marketing technique that is trying to attract the public. One of the woven fabric sales center in Denpasar, Ananda Tenun Bali, has used a variety of ways to market and introduce as well as commodify their woven fabrics to varieties of other useful items for the community. One of the latest marketing techniques that is done by Ananda is by using social media.

There are various ways that can be done by businesses in marketing their products, which some are by advertising in newspapers, distributing pamphlets, brochures, or perhaps among the most expensive one television advertising. But lately, with the increasing trend of social media users all over the globe, that is loved by all levels of society, not only by our young people but also by parents who initially just want to try the apps or who have felt the benefits directly, it could be one alternative marketing techniques that are not only cheap, but also can be very rewarding. This issue will be the subject of this study, to see how effective the promotion or marketing done via social media conducted by Ananda Weaving Bali in introducing their products.

At first glance, Ananda Tenun Bali which was inaugurated by the mayor of Denpasar on January 27, 2014, is committed to support local government programs of Denpasar to make Tenun as an icon of Denpasar and make Denpasar woven fabric as barometer of woven fabric in Bali, as well as in foreign countries. The gallery also provides a variety of Tenun modification options like a variety of clothing, such as a sheet of cloth, hats, slippers/shoes, and trinkets made from other woven fabric (source: Ananda website Weaving Bali) .In the case of promotion through social media, Ananda has a variety of social media accounts such as Facebook, Twitter, or Instagram in introducing their products. Before discussing how effective the marketing through the social media, first will be discussed the term social media marketing.

Viewing the meaning of the term 'social media', it can be derived from two words that form the term. Media generally refers to advertising and the communication of ideas or information through publications/channels. While the term Social implies the interaction of individuals within a group or community. Taken together, social media simply refers to communication/publication platforms which are generated and sustained by the interpersonal interaction of individuals through the specific medium or tool (Neti, 2011). From these terms, social media is a platform that is dependent on the interaction of many people through video, pictures, text and more that makes social media as a means of effective marketing. Added by Neti (2011), by citing Lazer and Kelly's (1973), states that social marketing applications connect social interaction as a whole, including for economic interests. That makes social media marketing is not solely put the product on social media pages, but rather how to put the idea of the company and the products that will influence the public by means of the social media.

There are two benefits of social media that are deemed important to businesses (Neti, 2011). They are 1.) Reduction of staff, thereby

reducing expenditure. It takes at least one staff on duty to do marketing promotion through social media. Compared with the common traditional marketing techniques, which can employ a number of workers on marketing alone, which makes social media marketing is considered the most effective in reducing the budget or cost needed to hire employees, so it will save more for the company; 2.) Great possibility to increase revenue. With the wide scope of marketing area, possibly the whole world, then it is likely able to increase target sales of the company. This will surely provide positive feedback to the company's balance sheet.

Besides the two main advantages delivered by Neti above, she added social media also has some social benefits for the company, including the opportunity to share experiences, able to capture consumer opinion, as a bridge between consumers in order for them to help each other, opportunities to obtain other consumers through former consumer, and of course the benefits included branch reach and awareness, consumer interactions through transactions, referrals and reputation management. With a wide range of social media benefits to the business, marketing and sales, become the basis of this study that will investigate on how effective the role of social media marketing by Ananda Tenun Bali in introducing Tenun fabrics.

\section{METHOD}

This research paper used the qualitative approach applied in the concept of creative marketing technique using social media. In terms of type of research, this study is focusing on descriptive research based on purpose and used qualitative data collection techniques through interviews, observation, questionnaires and literature study.

Interviews, questionnaires and observations were conducted for those actors who are involved directly to the process of social marketing in Ananda Tenun Bali, as well as the direct customers that happen to visit Ananda Tenun Bali during the research. Later on 
collected data were cross-checked with several literature reviews and explained descriptively to clear up the meaning.

\section{RESULT AND DISCUSSION}

Based on observations and data owned by Ananda Tenun Bali, It can be seen the increasing number of visits to the gallery from time to time, especially when Ananda take advantage of social media as a marketing tool.

Since it was established last 2014, Ananda only use website as a mean to introduce the products they have. There are a variety of products that have been made by Ananda using a piece of cloth as a basic material. They are slippers, shoes, hats, shirts, dresses, until basic things as sheet of Tenun fabric.

With a wide range of products owned by Ananda, it was deemed necessary to conduct marketing to introduce their products so that can be known by many people, as well as prospective customers, and able to interact actively with Anada Tenun Bali without having to come to their gallery in Denpasar. Given the website as well as "conventional" marketing techniques such as newspaper ads, magazine or television will only be one way communication, then the presence of social media is hoped to be the only reasonable option to achieve this goal, in addition to the nature of "low cost" offered. Since this time Ananda has opened multiple social media accounts such as Facebook, Instagram, and website to reach more customers and introduce products that they have. As a result, as what can be seen at the time of observation and the books they have, social media is reaping positive results.

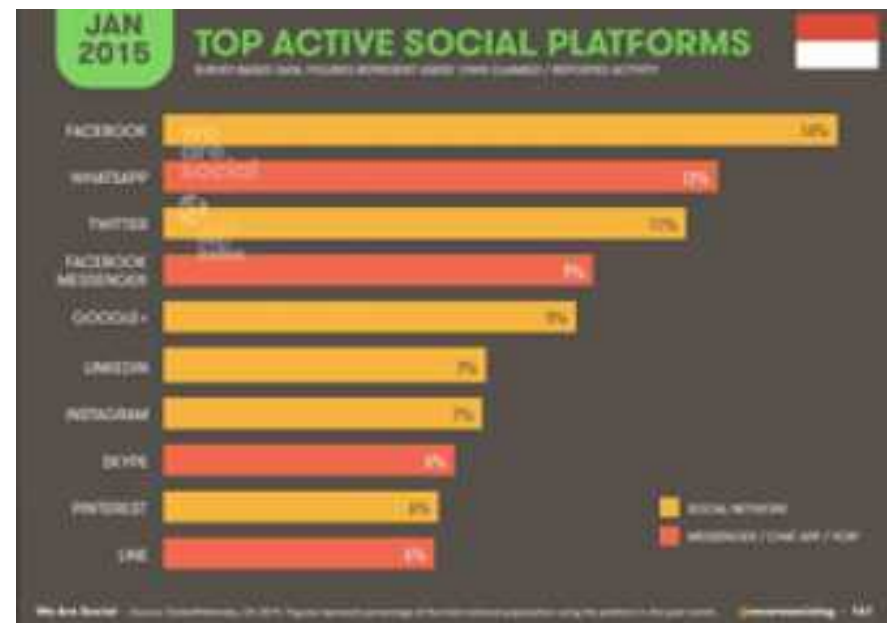

Fig. 1. Top Active Social Platform

Interview conducted on some consumers who happen to visit Ananda gallery revealed that most of them know Ananda from friends and word of mouth. But what makes it interesting, they, predominantly by youngsters, use the search facility on their smartphones to search for locations and products owned by Ananda. This proves that product's introduction through social media is quite powerful in attracting the target customers to come and shop at Ananda especially our youngers. Nevertheless, the highest trends of social media users are the teenagers. But that happens not only for young people, many consumers of Ananda are also dominated by middle age woman, who know the whereabouts of Ananda

products from social media, although most of these women are mothers of teenagers who are introducing Ananda social media accounts to their mother. By all means, it is still considered as a form of indirect introduction to the social media to these women.

With the increasing number of visits to Ananda Tenun Bali, as well as the influence of multiple social media accounts, sales in the gallery tends to increase considerably. After using social media as a campaign media and product introductions, the selling rate increased in about a 75\%.This data show a significant influence of social media towards sales of the products. This is also in line with what has been investigated by Neti (2011) which mentions that one of the benefits of social media for business is likely to increase revenue.

\section{CONCLUSION}

From the study it can be concluded that the influence of social media is very important from the standpoint of business. Many benefits can be drawn from the use of social media, among others is the projection of a broader product introduction and to increase sales. It has been proved by Ananda Tenun Bali, which has been using social media as a form of marketing to capture a wider market segment, introducing their products, and simultaneously increase sales. This of course can be emulated by other business centers in this age of globalization, where technology and active role of social media can greatly assist the growth of the business.

\section{REFERENCES}

Adnyani, Ida Ayu Sri. (2013). Rancang Bangun Alat Pemidangan Otomatis yang Ergonomis Meningkatkan Kinerja Perajin Kain Endek di Kecamatan Blahbatuh Gianyar. Disertasi. Universitas Udayana.

Ananda Bali. 2013. Tentang Ananda Tenun Bali. http://anandatenunbali.com/about-gallery- tenunananda-balinese/

BPS. 2015. Wisatawan Mancanegara yang Datang ke Indonesia Menurut Kebangsaan, 2000-2014. Retrieved

November,15,2015from:https://www.bps.go.id/linkTa belStatis/view/id/1394

Kemp, Simon. 2015. Digital, Social, and mobile 2015. Retrieved on October 21, 2016, from http://wearesocial.sg/blog/2015/01/digital- socialmobile-2015/

Kustiasih, Rini. (2014). Menemukan Kembali Tenun yang Hilang. Kompas Cetak. Retrieved from 
http://travel.kompas.com/read/2014/05/07/1751339/

Menemukan.Kembali.Tenun.yang.Hilang

Neti, Sisira. (2011). Social Media and Its Role in Marketing. International Journal of Enterprise Computing and Business Systems. Retrived from: http://www.ijecbs.com Vol. 1 Issue 2 July 2011

Oka A. Yoeti, (1997). Perencanaan dan Pengembangan Pariwisata. Jakarta : Pradnya Paramita

Putri, Deannisa Hakika. Suardana, I Wayan. Mananda, I GPB Sasrawan. (2015). Analisis Strategi Pemasaran Kain Endek Bali sebagai Industri Pariwisata Kreatif (Studi Kasus Denpasar). Jurnal IPTA Vol. 3 No. 2, 2015. ISSN : 2338-8633.

Wirawan, A.A. Bagus. et.al. (2011). Sejarah Kota Denpasar: Dari Kota Keraton Menjadi Kota (1788-2010). Kerjasama: Badan Perencanaan Pembangunan Daerah (Bappeda) Kota Denpasar dan Universitas Udayana.

Utami, Sri. (2015). Tenun Gringsing, Korelasi Motif, Fungsi, dan Arti Simbolik. Journal of ISI Yogyakarta. 